\title{
Deteksi Dini Tekanan Darah Dan Kadar Gula Darah Sebagai Pencegahan Kegawatdaruratan Penyakit Jantung
}

\author{
Ai Cahyati, Sofia Februanti, Syaukia Adini \\ Prodi Ners Tasikmalaya, Poltekkes Kemenkes Tasikmalaya \\ Email: cahyati94@gmail.com
}

\begin{abstract}
ABSTRAK
Penyakit jantung merupakan penyebab kematian nomor satu di Indonesia. Masih Banyak penduduk Indonesia yang tidak menyadari tingginya resiko terkena penyakit ini. Faktor resiko penyakit ini adalah usia, jenis kelamin, keturunan, riwayat merokok, diabetes mellitus, hipertensi, hiperkolesterol, manajemen stress yang tidak baik. Tujuan kegiatan ini adalah untuk pemberdayaan kesehatan yaitu kader Kesehatan dalam melakukan deteksi dini factor risiko penyakit jantung coroner serta penyuluhan cara pencegahannya sebagai pencegahan kegawatdaruratan penyakit jantung. Sasarannya adalah masyarakat usia dewasa sampai usia maksimal 50 tahun di wilayah Setiajaya, Cibeureum, Tasikmalaya sebanyak 25 orang. Targetnya adalah masyarakat di wilayah Setiajaya, Cibeureum Tasikmalaya. Metode yang digunakan pada kegiatan ini adalah dengan menitikberatkan pada pemberdayaan masyarakat (kader Kesehatan) yang telah dilatih untuk melakukan deteksi dini dan pemberian pendidikan tentang pencegahan faktor risiko penyakit jantung koroner. Kader Kesehatan terlebih dulu dilatih cara mengisi kuesioner, cara pengukuran tekanan darah, cara pengukuran gula darah sewaktu, dan diberi penjelasan cara pencegahan penyakit jantung coroner. Kemudian kader mengambil data ke masyarakat untuk melakukan deteksi dini factor risiko penyakit jantung coroner dan malakukan pendidikan Kesehatan dengan media yang telah disediakan. Hasil kegiatan menunjukkan terdapat 9 orang (36 \%) yang mengalami hipertensi dan 9 orang (36\%) yang mengalami diabetes mellitus. Deteksi dini ini digunakan sebagai data awal mendeteksi faktor risiko penyakit jantung sebagai pencegahan kegawatdaruratan penyakit jantung.
\end{abstract}

Kata kunci: deteksi dini, penyakit jantung, tekanan darah

\begin{abstract}
Heart disease is the number one cause of death in Indonesia. There are still many Indonesians who do not realize the high risk of getting this disease. Risk factors for this disease are age, gender, heredity, smoking history, diabetes mellitus, hypertension, hypercholesterolemia, poor stress management. This activity aims to to empower health, namely health cadres in conducting early detection of risk factors for coronary heart disease and providing counseling on how to prevent it as a prevention of heart disease emergencies. The target is 25 people from adults to a maximum age of 50 in the Setiajaya, Cibeureum, Tasikmalaya area. The method used in this activity is to focus on community empowerment (health cadres) who have been trained to carry out early detection and provide education on the prevention of coronary heart disease risk factors. Health cadres were first trained on how to fill out questionnaires, how to measure blood pressure, how to measure blood sugar at any time, and were explained how to prevent coronary heart disease. Then the cadres take data from the public to conduct early detection of risk factors for coronary heart disease and conduct health education using the media provided. The results showed that there were 9 people (36\%) who had hypertension and 9 people (36\%) who had diabetes mellitus. This early detection is used as initial data to detect risk factors for heart disease as a prevention of heart disease emergencies.
\end{abstract}

Keywords: early detection, heart disease, blood pressure 


\section{PENDAHULUAN}

WHO menjelaskan bahwa penyebab kematian terbesar di dunia adalah karena penyakit kardiovaskuler, atau sekitar 17,9 juta setiap tahun (WHO, 2017). Secara global, Penyakit tidak menular (PTM) penyebab kematian nomor satu setiap tahunnya adalah penyakit kardiovaskuler. Penyakit kardiovaskuler adalah penyakit yang disebabkan gangguan fungsi jantung dan pembuluh darah, seperti:Penyakit Jantung Koroner, Penyakit Gagal jantung atau Payah Jantung, Hipertensi dan Stroke. Komplikasi hipertensi menyebabkan sekitar 9,4 kematian di seluruh dunia setiap tahunnya. Hipertensi menyebabkan setidaknya $45 \%$ kematian karena penyakit jantung dan 51\% kematian karena penyakit stroke. Kematian yang disebabkan oleh penyakit kardiovaskuler, terutama penyakit jantung koroner dan stroke diperkirakan akan terus meningkat mencapai 23,3 juta kematian pada tahun 2030 (Pusdatin Kemenkes RI, 2014).

Coronary Artery Disease (CAD) atau Penyakit Jantung Koroner (PJK) adalah suatu penyempitan arteri koroner ditandai oleh deposisi lemak pada lapisan intima arteri, selanjutnya terjadi kalsifikasi, fibrosis, trombosis dan pendarahan dan hal tersebut membantu terbentuknya plak aterosklerosis (Ali et al., 2020). CAD merupakan suatu tipe gangguan pada pembuluh darah yang termasuk pada kategori atherosklerosis, yang disebut juga proses pengerasan pembuluh darah arteri, yang melalui proses pembentukan plak, deposit atheromatous dan oklusi koroner. Faktor resiko PJK terdiri dari dua yaitu yang bisa dirubah: diabetes melitus, hiperkolesterol, hipertensi, merokok; dan faktor yang tidak bisa dirubah adalah jenis kelamin, usia. Wilayah Setiajaya, Cibeureum Tasikmalaya belum dilaksanakan deteksi dini dan pencegahan penyakit jantung koroner.

Tujuan kegiatan ini adalah pemberdayaan kesehatan yaitu kader Kesehatan dalam melakukan deteksi dini factor risiko penyakit jantung coroner serta penyuluhan cara pencegahannya.

\section{BAHAN DAN METODE}

Kegiatan pengabdian kepada masyarakat ini adalah untuk melakukan deteksi dini dan pencegahan penyakit jantung coroner melalui pemberdayaan masyarakat (kader Kesehatan). Disamping deteksi dini factor risiko penyakit jantung coroner dalam kegiatan ini juga mengimplementasikan hasil penelitian yaitu Progresive Muscle Relaxation (PMR) dalam meningkatkan saturasi oksigen pasien dengan penyakit jantung coroner. Hasil penelitian ini dapat diterapkan di masyarakat sebagai upaya meningkatkan relaksasi sehingga suplai darah ke seluruh tubuh lancar. Mitra dalam penelitian ini adalah Puskesmas Kersanegara. Peran Puskesmas Kersanegara adalah memberikan gambaran pelaksanaan deteksi dini risiko penyakit jantung coroner yang merupakan bagian dari Program Penyakit Tidak Menular (PTM) di puskesmas. Dilaksanakan pada bulan Februari sampai dengan November 2020 di wilayah Gunung Daning, Setiajaya, Wilayah kerja Puskesmas Kersanegara, Cibeureum Tasikmalaya. Pembekalan kader kesehatan tentang cara pemberian penjelasan tentang penyakit jantung coroner, factor risiko serta pencegahannya:

Kader diberi penjelasan tentang kuesioner yang berisikan biodata, factor risiko yang tidak dapat dirubah, serta pre dan posttest. Kader diberi penjelasan tentang cara mengukur tekanan darah, dan gula darah. Kader juga dibekali media Pendidikan Kesehatan (leaflet). Pemberdayaan masyarakat (kader kesehatan) dalam melakukan pretest dan deteksi dini factor risiko penyakit jantung coroner: pengukuran tekanan darah dan gula darah sewaktu \& pendidikan kesehatan pencegahannya. Kader Kesehatan memberikan media Pendidikan Kesehatan (leaflet pencegahan dan pengendalian faktor risiko penyakit jantung coroner) pada masyarakat. Pada bagian akhir, kader kesehatan melakukan posttest.

\section{HASIL}

Rata-rata usia sasaran adalah 42 tahun. Sebagian besar sasaran berusia lebih dari 42 tahun (64 \%). Sebagian besar sasaran berjenis kelamin perempuan (72\%). Prosentase 
sasaran yang mempunyai riwayat keluarga sakit jantung atau hipertensi adalah $64 \%$. Faktor risiko yang dapat di ubah adalah obesitas, merokok, diabetes melitus, hipertensi dan hiperlipidemia. Dalam kegiatan ini yang dilakukan deteksi dini adalah terhadap faktor risiko merokok, diabetes melitus dan hipertensi. Sebagian besar sasaran merokok (64 \%), jumlah sasaran yang hipertensi berjumlah $36 \%$, dan yang pre hipertensi $16 \%$. Sasaran yang mengalami kenaikan gula darah sewaktu berjumlah $36 \%$.

Pengetahuan masyarakat tentang penyakit jantung coroner dan pencegahannya diukur dengan pre dan posttest. Pretest diberikan sebelum masyarakat mendapat penjelasan tentang penyakit jantung coroner dan pencegahannya oleh kader, dan posttest setelah mendapat penjelasan dari kader serta dibekali media pendidikan kesehatan berupa leaflet. Pada saat pretest sebagian besar sasaran mempunyai pengetahuan yang cukup tentang factor risiko penyakit jantung coroner dan pencegahannya (64 \%), dan yang mempunyai pengetahuan yang kurang sejumlah $32 \%$. Setelah diberi pendidikan kesehatan oleh kader kesehatan, diberi media leaflet, terjadi peningkatan tingkat pengetahuan sasaran yaitu Sebagian besar sasaran berpengetahuan baik (82 \%) dan yang pengetahuan cukup menurun dari sebelum posttest dari $64 \%$ menjadi $12 \%$, dan setelah diberi penjelasan sasaran tidak ada yang berpengetahuan kurang.

\section{PEMBAHASAN}

Faktor risiko penyakit jantung coroner terdiri dari dua yaitu faktor yang tidak bisa dirubah dan factor yang bisa dirubah. Usia merupakan faktor risiko terjadinya penyakit jantung koroner, karena semakin tua terjadi penurunan kualitas anatomi dan fungsi dari struktur pembuluh darah (Bit, Suri, \& Mishra, 2020).

Sebagian besar sasaran berjenis kelamin perempuan (72 \%). Berdasarkan teori diungkapkan bahwa jenis kelamin laki-laki memiliki risiko terkena penyakit jantung coroner dibanding wanita, tetapi wanita yang telah menopause mempunya risiko yang sama dengan laki-laki untuk terkena penyakit jantung coroner (Kane \& Howlett, 2018). Prosentase sasaran yang mempunyai riwayat keluarga sakit jantung atau hipertensi adalah $64 \%$, Riwayat keluarga sakit jantung ini merupakan suatu keadaan yang harus diwaspadai oleh masyarakat dengan mempertahankan pola hidup sehat supaya tidak terserang penyakit jantung.

Selain faktor yang tidak dapat diubah, terdapat beberapa faktor yang dapat dimodifikasi sehingga dapat diminimalisir risiko terjadinya penyakit jantung coroner. Merokok merupakan faktor risiko terjadinya penyakit jantung coroner, karena dalam rokok terdapat zat-zat yang akan merusak struktur pembuluh darah (Tang et al., 2020; Feodoroff, Harjutsalo, Forsblom, \& Groop, 2018). Selain merokok, hipertensi juga merupakan faktor risiko terkena penyakit jantung koroner yang dapat diubah (Meissner, 2016). Pada hasil kegiatan, dapat diketahui jumlah sasaran yang hipertensi berjumlah $36 \%$, dan yang pre hipertensi $16 \%$. Walaupun pengukuran ini baru pengukuran satu kali, tetapi hasil pengukuran ini merupakan sinyal yang harus diwaspadai oleh masyarakat.

Sasaran yang mengalami kenaikan gula darah sewaktu berjumlah $36 \%$. Kenaikan gula darah ini harus diwaspadai, walaupun yang pengukuran menggunakan pengukuran gula darah sewaktu bukan menggunakan pengukuran gula darah puasa dan gula darah 2 jam post puasa, tetapi pengukuran ini merupakan skrining awal terhadap diabetes melitus bagi sasaran.

Pengetahuan merupakan kunci utama dalam keberhasilan pencegahan penyakit jantung coroner, pengetahuan merupakan bekal untuk mengimplementasikan pencegahan penyakit jantung coroner dalam kehidupan sehari-hari. Dalam peningkatan pengetahuan ini dilakukan melakukan Pendidikan Kesehatan oleh kader tentang cara-cara pencegahan dan pengendalian factor risiko penyakit jantung coroner juga diajarkan tentang praktek Progresive Muscle Relaxation (PMR) yang merupakan hasil penelitian sebagai upaya untuk menambah kualitas hidup dengan meningkatkan relaxasi (Cahyati, Herliana, \& Februanti, 2020). Dari hasil kegiatan, dapat dilihat peningkatan yang signifikan tingkat pengetahuan 
sasaran dari sebelum dilakukan pendidikan kesehatan dan seteleh dilakukan pendidikan kesehatan.

\section{KESIMPULAN DAN SARAN}

Pemberdayaan masyarakat (kader Kesehatan) mulai dari screening faktor risiko yang tidak dapat dirubah, pengukuran tekanan darah, pengukuran gula darah dapat dilaksanakan dengan baik. Untuk masyarakat diharapkan dapat mengenali factor risiko penyakit jantung coroner sehingga dapat melakukan tindakan pencegahannya berupa pengendalian faktor risiko. Masyakat yang telah mempunyai factor risiko harus patuh terhadap program pengobatan

\section{UCAPAN TERIMA KASIH}

Kami mengucapkan terima kasih kepada semua pihak yang telah membantu dalam kegiatan pengabdian kepada masyarakat ini, Direktur Poltekkes Kemenkes Tasikmalaya, Kepala Puskesmas Kersanegara,dan kader kesehatan wilayah Setiajaya.

\section{DAFTAR PUSTAKA}

Ali, H., Atici, A., Sahin, I., Alici, G., Aktas, E., Faruk, Ö., ... Oktay, A. (2020). Prognostic significance of cardiac injury in COVID-19 patients with and without coronary artery disease. Coronary Artery Disease, (March), 1-8. https://doi.org/10.1097/MCA.0000000000000914

Bit, A., Suri, J. S., \& Mishra, B. (2020). Flow Dynamics and Tissue Engineering of Blood Vessels. England: IOP Publishing Ltd.

Cahyati, A., Herliana, L., \& Februanti, S. (2020). Progressive Muscle Relaxation ( PMR ) Enhances Oxygen Saturation in Patients of Coronary Heart Disease. In 2nd lccomset (pp. 1-5). Tangerang: IOP Publishing Ltd. https://doi.org/10.1088/17426596/1477/6/062018

Feodoroff, M., Harjutsalo, V., Forsblom, C., \& Groop, P. (2018). Dose-dependent effect of smoking on risk of coronary heart disease, heart failure and stroke in individuals with type 1 diabetes. Diabetologia, 61, 2580-2589.

Kane, A. E., \& Howlett, S. E. (2018). Differences in Cardiovascular Aging in Men and Women. Sex-Specific Analysis of Cardiovascular Function, 1065(7), 389-411.

Meissner, A. (2016). Hypertension and the Brain: A Risk Factor for More Than Heart Disease. Cerebrovascular Diseases, 42, 255-262. https://doi.org/10.1159/000446082

Pusdatin Kemenkes RI. (2014). Situasi Kesehatan Jantung. Jakarta.

Tang, R., Yang, S., Liu, W., Yang, B., Wang, S., Yang, Z., \& He, Y. (2020). Smoking Is a Risk Factor of Coronary Heart Disease through HDL-C in Chinese T2DM Patients: A Mediation Analysis. Journal of Healthcare Engineering, 1-8.

WHO. (2017). Cardiovascular Diseases. 


\section{LAMPIRAN}

Tabel 1. Distribusi factor risiko penyakit jantung coroner yang tidak dapat dirubah

di masyarakat Setiajaya, Cibeureum, Tasikmalaya Wilayah kerja

Puskesmas Kersanegara

\begin{tabular}{|l|c|c|}
\hline \multicolumn{1}{|c|}{ Faktor risiko } & $\begin{array}{c}\text { Frekuensi } \\
\text { (orang) }\end{array}$ & $\%$ \\
\hline Usia & 9 & 36 \\
$<42$ tahun & 16 & 64 \\
$\geq 42$ tahun & 7 & \\
\hline Jenis Kelamin & 18 & 72 \\
- Laki-laki & & \\
- Perempuan & 16 & 64 \\
\hline Riwayat Keturunan & 9 & 36 \\
- Tidak ada & & \\
- Ada & & \\
\hline
\end{tabular}

Tabel 2. Distribusi factor risiko penyakit jantung coroner yang dapat dirubah

di masyarakat Setiajaya, Cibeureum, Wilayah kerja Puskesmas Kersanegara

\begin{tabular}{|l|c|l|}
\hline \multicolumn{1}{|c|}{ Faktor risiko } & Frekuensi (orang) & $\%$ \\
\hline Merokok & 9 & \\
- Tidak & 16 & 36 \\
- Merokok & & 64 \\
\hline Hipertensi & 12 & 48 \\
- Tidak hipertensi & 4 & 16 \\
- Prehipertensi & 9 & 36 \\
- Hipertensi & & \\
\hline Diabetes Melitus & 16 & 64 \\
- Tidak ada & 9 & 36 \\
- Ada & \multicolumn{2}{|c|}{} \\
\hline
\end{tabular}

Tabel 3. Hasil Pre dan Posttest tentang Penyakit Jantung Koroner dan Pencegahan di masyarakat Setiajaya, Cibeureum, Wilayah kerja Puskesmas Kersanegara

\begin{tabular}{|l|c|c|}
\hline \multicolumn{1}{|c|}{ Tingkat Pengetahuan } & Frekuensi (orang) & $\%$ \\
\hline Pretest & 8 & \\
- Kurang (jawaban benar <56\%) & 16 & 32 \\
- Cukup (jawaban benar 56\% - & 1 & 64 \\
$75 \%$ ) & 4 \\
- Baik (jawaban benar 76\% - 100\%) & & \\
\hline $\begin{array}{l}\text { Posttest } \\
\text { - Kurang (jawaban benar <56\%) }\end{array}$ & 0 & 0 \\
\hline
\end{tabular}




\begin{tabular}{|c|c|c|}
\hline - Cukup (jawaban benar 56\% - & 3 & 12 \\
$75 \%)$ & 22 & 82 \\
- Baik (jawaban benar 76\% - 100\%) & & \\
\hline
\end{tabular}

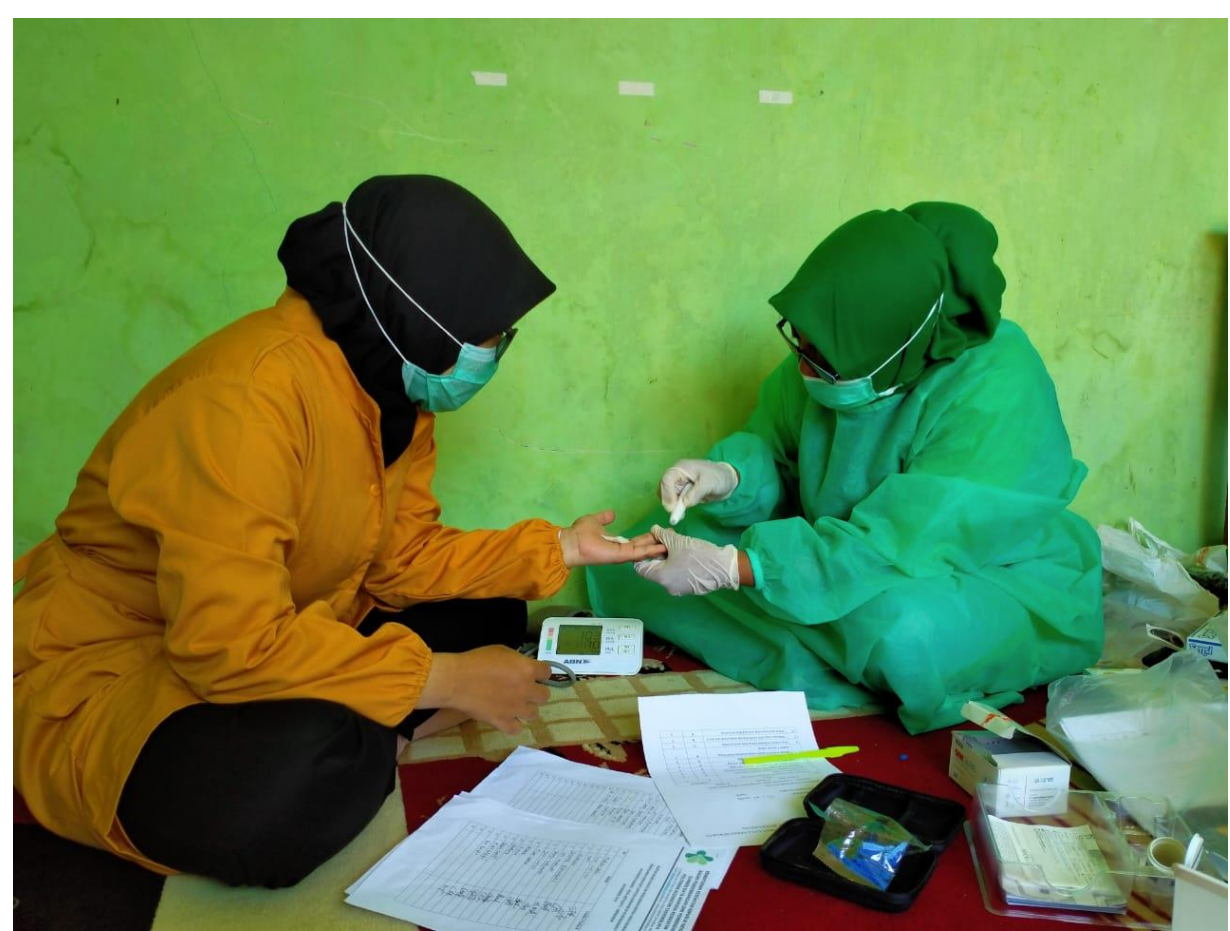

Sumber: dokumentasi kegiatan pengabdian kepada masyarakat tim

Gambar 1. Pengambilan sampel kadar gula darah sewaktu 